\title{
Pemanfaatan Bakteri Asam Laktat yang Di Isolasi Dari Saluran Pencernaan Ayam Lokal Untuk Pembuatan VCO Secara Fermentasi
}

\author{
Husnul Khotimah ${ }^{1 *}$, Laelatul Baniyah ${ }^{2}$, Imam Hanafi ${ }^{3}$, Permadi Wisnu Aji Wardani. ${ }^{4}$, \\ Saskia Maisi Monika Sari. ${ }^{5}$, dan Siti Nur Jannah ${ }^{6 *}$ \\ ${ }^{1,2,6}$ Departemen Biologi, Fakultas Sains dan Matematika, Universitas Diponegoro \\ Jl. Prof Soedharto, SH, Tembalang, Semarang 50275 \\ ${ }^{3}$ Departemen Fisika Fakultas Sains dan Matematika, Universitas Diponegoro \\ Jalan Prof. H. Soedarto, SH, Tembalang, Kota Semarang Kode Pos 50275 Indonesia \\ ${ }^{4,5}$ Departemen Teknik Kimia Fakultas Teknik, Universitas Diponegoro \\ Jalan Prof. H. Soedarto, SH, Tembalang, Kota Semarang Kode Pos 50275 Indonesia \\ ima.husnulkhotimah@gmail.com
}

\begin{abstract}
Abstrak
Indonesia merupakan negara tropis yang memiliki banyak pulau dan merupakan negara produsen kelapa utama di dunia. .Pada tahun 2014 luas areal perkebuan tanaman kelapa di dunia mencapai 11 juta ha dan 93\% berada di wilayah Asia Pasifik. Hal ini merupakan peluang untuk pengembangan kelapa menjadi aneka produk yang bermanfaat. Salah satu pemanfaatan kelapa dalam bidang kesehatan dalam upaya mendukung visi Indonesia sehat 2015 adalah dengan adanya VCO (virgin coconut oli). Proses pembuatan VCO adalah dengan cara fermentasi tidak mengalami proses pemanasan dan difermentasi dengan menggunakan bakteri asam laktat hasil dari isolasi pada saluran pencernaan ayam lokal, sehingga VCO yang dihasilkan memiliki kualitas yang baik. Berdasarkan uji fisik (uji viskositas) menunjukkan sampel $\mathrm{H}$ dengan isolat BUB 3 bahwa nilai viskositas sebesar 58,4325 Pa.s dan densitas $937,5 \mathrm{Kg} / \mathrm{m}^{3}$. Pada uji kimia (uji asam lemak bebas) didapatkan hasil kadar asam lemak bebas sampel H (BUB 3) dengan paling mendekati kadar asam lemak bebas menurut SNI 7381 tahun 2008 tentang VCO yaitu kadar asam lemak bebas maksimal dalam VCO adalah sebesar $0,2 \%$. Sedangkan berdasarkan uji hasil pengujian organoleptik dari 11 koresponden didapatkan hasil bahwa tingkat kesukaan dari koresponden terhadap tekstur dari sampel VCO yaitu 7, yang berarti suka. Tingkat kesukaan terhadap aroma dari sampel VCO yaitu 7, yang berarti suka. Tingkat kesukaan terhadap rasa dari sampel VCO yaitu 5, yang berarti netral. Sedangkan tingkat kesukaan terhadap warna dari sampel VCO yaitu 5, yang berarti netral dan menunjukkan kualitas VCO yang didapatkan baik.
\end{abstract}

Kata kunci: VCO, BAL, saluran pencernaan ayam, fermentasi

\section{PENDAHULUAN}

Indonesia merupakan salah satu negara penghasil tanaman kelapa terbesar di dunia. Negara penghasil kopra dunia adalah Indonesia, Filipina, India, Sri Lanka, Thailand, Vietnam, malaysia, Papua New Guinea, Vanuatu, Kepulauan Solomon Barat, Fiji dan Mikronesia. Data dari Asian and Pacific Coconut Community (APCC, 2010). Buah kelapa sebagai salah satu hasil perkebunan merupakan bahan baku berbagai produk makanan dan bukan makanan. Buah kelapa mengandung nilai gizi yang tinggi. Daging buah kelapa mengandung protein, karbohidrat dan lemak yang sangat penting serta vitamin. Sekitar 90\% asam lemak dalam daging buah kelapa adalah asam lemak jenuh dan $10 \%$ sisanya adalah asam lemak tidak jenuh (Karouw dan Tenda, 2006). Santan kelapa mengandung 54\% air, 35\% lemak dan $11 \%$ padatan non lemak (Tansakul dan Chaisawang, 2006).

Pemanfaatan bakteri asam laktat sebagai mikroorganisme yang tidak menimbulkan toksin dan mempunyai potensi sebagai bakteri fermentasi untuk bahan pangan yang mampu memanfaatkan oligosakarida dan protein, mengubahnya menjadi asam laktat dan metabolit-metabolit lainnya (Surono, 2004). Menurut Yang et al. (2012) senyawa antimikroba yang dihasilkan BAL untuk menghambat bakteri patogen dan pembusuk itu antara lain adalah asam organik, hydrogen 
peroksida, diasetil, $\mathrm{CO}_{2}$, dan bakteriosin. Oleh karena itu, BAL juga sering dikenal sebagai agen probiotik dan biopreservasi. BAL merupakan mikroorganisme yang Generally Recognized as Safe (GRAS) yaitu mikroorganisme yang tidak berisiko terhadap kesehatan. BAL tidak menghasilkan toksin sehingga aman jika ditambahkan dalam pangan (food grade microorganism), bahkan beberapa jenis bakteri tersebut berguna bagi kesehatan (Kusmiati dan Malik, 2002; Fawzya, 2010).

Bakteri asam laktat secara umum, terbukti mampu menginduksi proses pemisahan minyak dan air dari santan kelapa (Che Man et al. 1997). Kondisi ekstraksi tanpa melibatkan panas dan mekanis pada proses fermentasi VCO-BAL dianggap memiliki banyak keuntungan seperti kadar bilangan penyabunan, bilangan peroksida, dan asam lemak bebas yang rendah, dan sifat antibakteri yang diklaim lebih tinggi (Ali dan Dwiyana, 2005). Hingga saat ini, publikasi yang membandingkan proses fermentasi VCO menggunakan beberapa jenis BAL untuk mengkonfirmasi keunggulan yang dimiliki oleh VCO-BAL masih sangat terbatas.

Virgin coconut oil atau minyak kelapa murni mengandung asam lemak rantai sedang yang mudah dicerna dan dioksidasi oleh tubuh sehingga mencegah penimbunan di dalam tubuh. Di samping itu ternyata kandungan antioksidan di dalam VCO pun sangat tinggi seperti tokoferol dan betakaroten. Antioksidan ini berfungsi untuk mencegah penuaan dini dan menjaga vitalitas tubuh (Setiaji dan Prayugo, 2006).

Oleh karena itu, dilakukan penelitian pembuatan VCO dengan penambahan bakteri asam laktat (BAL) dengan tujuan untuk mengetahui metode pembuatan VCO mana yang menghasilkan kadar minyak paling tinggi serta kadar air, asam lemak bebas dan bilangan peroksida paling rendah dan mempercepat proses fermentasi untuk menghasilkan VCO yang berkualitas baik serta rendemen yang tinggi.

\section{BAHAN DAN METODE}

Penelitian ini dilaksanakan di Laboratorium Mikrobiologi, Biologi, Fakultas Sains dan Matematika, Universitas Diponegoro. Metode penelitian ini menggunakan Rancangan Acak Lengkap (RAL).

\section{Alat dan Bahan}

Peralatan yang diperlukan dalam penelitian ini yaitu laminar air flow, autoklaf, inkubator, jarum ose, bunsen, cawan petri, tabung reaksi, mikropipet, tip, parutan, pemeras santan, baskom, toples besar, saringan, pengaduk, mangkuk kecil, botol kaca besar, botol kaca kecil, kertas saring, spektrofotometer, gelas beker, pengaduk, kertas saring, erlenmeyer, corong, vorteks, pipet, corong gelas, gelas ukur.

Bahan yang diperlukan dalam penelitian ini yaitu daging buah kelapa, isolat Bakteri asam laktat yang diisolasi dari saluran pencernaan ayam lokal, medium MRSB, gas $\mathrm{CO}_{2}$ dan $\mathrm{N}_{2} \mathrm{O}, \mathrm{KOH}$, Alkohol netral, aquades, $\mathrm{HCl}$, asam asetat glasial, klorofom, larutan KI jenuh, larutan standar Natrium tiosulfat.

\section{Cara Kerja}

\section{A. Pembuatan VCO dengan Bakteri Asam}

\section{Laktat}

Diagram alir pembuatan VCO secara fermentasi dengan bakteri asam laktat yaitu sebagai berikut:

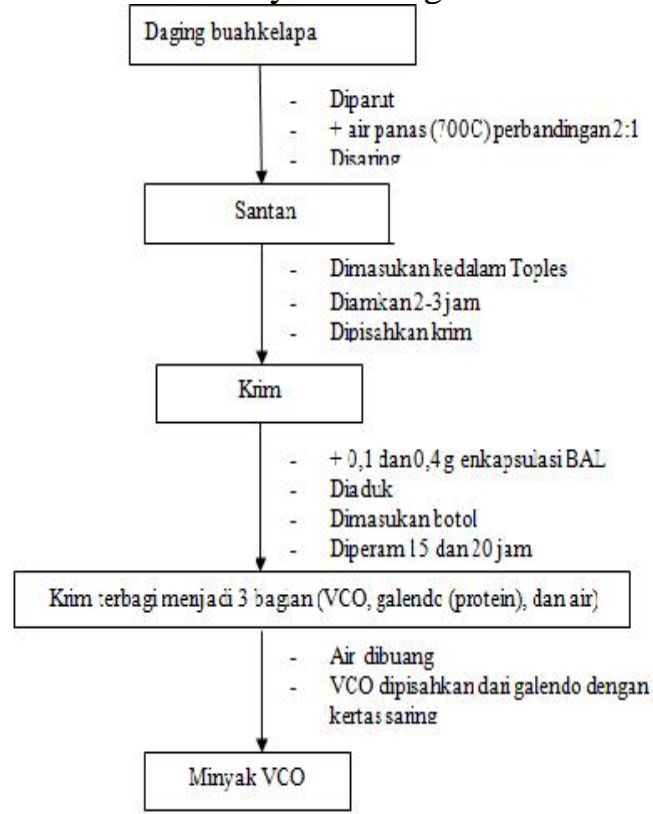

\section{HASIL DAN PEMBAHASAN}

Penelitian ini diawali dengan studi pustaka dan isolasi bakteri asam laktat dari saluran pencernaan ayam lokal dengan menggunakan media MRS (Mann de Rogosa Shape) agar pada 
cawan petri. Tahapan selanjutnya dilakukan persiapan alat-alat dan bahan yang digunakan selama penelitian. Tahapan persiapan meliputi persiapan alat-alat parutan, pemeras santan, baskom, toples besar, pengaduk, mangkuk kecil, botol kaca besar, botol kaca kecil, kertas saring, spektrofotometer, gelas beker, pengaduk, kertas saring, erlenmeyer, corong, vorteks. Bahan yang diperlukan yaitu daging buah kelapa, isolat bakteri asam laktat yang diisolasi dari saluran pencernaan ayam lokal, medium MRS Broth, $\mathrm{NaOH}, \mathrm{KOH}$, Alkohol 96\%, indikator PP, etanol 95\%, aquades, $\mathrm{HCl}$.

Tahapan selanjutnya dilakukan pembuatan VCO dengan menggunakan 10 isolat yang telah terpilih yaitu V.5.2, BUB 1, V.3.2, No name A, no name B, BUB 3, C.5.1, BUB 4, S.3.3, V.5.3. Penelitian ini dilakukan dengan metode Rancangan Acak Lengkap (RAL) dengan 2 kali ulangan. Pembuatan VCO ini dilakukan dengan cara santan didiamkan sekitar 2-3 jam untuk mendapatkan 3 lapisan yaitu krim (lapisan bagian atas), protein atau gelendo dan skim (lapisan bagian bawah) dan air dibagian paling bawah. Pembuatan VCO membutuhkan krim (lapisan bagian atas), sedangkan pembuatan starter bakteri asam laktat menggunakan skim (lapisan bagian bawah). Sebelum pembuatan VCO, dilakukan pembuatan starter terlebih dahulu yaitu skim diberi isolate bakteri asam laktat yang telah ditumbuhkan dalam media cair sebelumnya sebanyak $1 \mathrm{ml}$ dan diinkubasi pada suhu $37^{\circ} \mathrm{C}$ selama 24 jam (overnight). Selanjutnya hasil starter tersebut yang akan digunakan untuk pembuatan VCO pada krim santan. Cara pembuatan VCO yaitu krim santan diberi starter bakteri asam laktat sebanyak $1 \mathrm{ml}$ kemudian diinkubasi pada suhu $37^{\circ} \mathrm{C}$ selama 20 jam. Kemudian krim tersebut terbagi menjadi 2 lapisan yaitu minyak dan protein atau gelendo.

Tahapan selanjutnya setelah didapatkan VCO dari hasil fermentasi bakteri asam laktat dilakukan pengujian secara fisik (uji viskositas), kimia (uji asam lemak bebas/ FFA), organoleptik (tekstur, aroma, rasa, warna) serta uji antimkroba. Untuk memudahkan pengujian hasil isolat yang digunakan pada pembuatan VCO diberi beri kode nama sebagai berikut: kontrol (A), V.5.2 (B), BUB 4 (C), no name a (D), S.3.3 (E), C.5.1 (F), BUB $1(\mathrm{G})$, BUB $3(\mathrm{H})$, V.3.2 (I), no name B (J), V.5.3 (K).
Uji Fisik (Uji Viskositas)

Berdasarkan hasil pengujian secara fisik yaitu dengan uji viskositas didapatkan hasil sebagai berikut:

Tabel. 1. Hasil Uji Fisik VCO

\begin{tabular}{c|c|c}
\hline Sampel & Densitas (kg/m3) & Viskositas (Pa.s) \\
\hline A & 917,5 & 48,603049 \\
\hline B & 920 & 55,0480896 \\
\hline C & 920 & 52,4677104 \\
\hline D & 937,5 & 54,14745 \\
\hline E & 942,5 & 57,5692572 \\
\hline F & 917,5 & 50,4189371 \\
\hline G & 870 & 49,70658 \\
\hline H & 937,5 & 58,4325 \\
\hline I & 915 & 53,5132626 \\
\hline J & 900 & 53,103456 \\
\hline K & 932,5 & 54,4398722 \\
\hline
\end{tabular}

Berdasarkan hasil pengujian viskositas tersebut diketahui bahwa nilai viskositas tertinggi terdapat pada sampel $\mathrm{H}$ dengan nilai viskositas sebesar 58,4325 Pa.s dan densitas 937,5 $\mathrm{Kg} / \mathrm{m}^{3}$. Hal ini menunjukkan nilai viskositas yang tinggi dapat menurunkan rasa lapar dan secara signifikan dapat meningkatkan rasa kenyang (Marciani dkk, 2001). Terlebih VCO mengandung komposisi MCFA (Medium Chain Fatty Acid) yang merupakan sumber energi instan sehingga dapat dimetabolisme dengan cepat menjadi energi. Sedangkan nilai viskositas yang paling rendah terdapat pada sampel A yang merupakan sampel kontrol dengan nilai viskositas sebesar 48,608049 Pa.s dengan densitas $917,5937,5 \mathrm{Kg} / \mathrm{m}^{3}$. Hal ini menunjukkan bahwa penambahan bakteri asam laktat dapat meningkatkan tingkat viskositas dari VCO yang dihasilkan.

Uji Kimia (Uji Asam Lemak Bebas/ FFA)

Berdasarkan hasil pengujian secara kimia yaitu dengan uji asam lemak bebas didapatkan hasil sebagai berikut: 
Tabel. 2. Hasil Uji Kimia VCO

\begin{tabular}{lcccc} 
Variabel & Berat & Volume Titran & FFA (\%) & Rank Kualitas \\
\hline A (kcntrcl) & 17.9 & 5.9 & 0.66 & 11 \\
B (V.5.2) & 13.2 & 3.5 & 0.53 & 6 \\
C (BUB 4) & 12.3 & 2 & 0.33 & 2 \\
D (No name a) & 10.1 & 2.5 & 0.50 & 5 \\
E (S.3.3) & 10.3 & 2 & 0.39 & 3 \\
F(C.5.1) & 11.6 & 3.2 & 0.55 & 7 \\
G (BUB l) & 13.2 & 4 & 0.61 & 10 \\
H (BUB 3) & 11.3 & 1.5 & 0.27 & 1 \\
I(V.3.2) & 10.8 & 3 & 0.56 & 8 \\
J(Noname b) & 11.7 & 2.7 & 0.46 & 4 \\
K (V.5.3) & 10 & 2.8 & 0.56 & 9 \\
\hline
\end{tabular}

Berdasarkan penelitian yang telah dilakukan pada sampel VCO mengenai kadar asam lemak bebas (FFA), pada sampel A didapatkan kadar FFA sebesar 0,66\%, B sebesar 0,53\%, C sebesar 0,33\%, D sebesar $0,5 \%$, E sebesar $0,39 \%$, F sebesar $0,55 \%$, $\mathrm{G}$ sebesar $0,61 \%$, H sebesar $0,27 \%$, I sebesar $0,56 \%$, J sebesar $0,46 \%$, dan $\mathrm{K}$ sebesar $0,56 \%$. Berdasarkan hasil tersebut, hasil uji kadar asam lemak bebas didapatkan kadar asam lemak bebas sampel $\mathrm{H}$ paling mendekati kadar asam lemak bebas menurut SNI 7381 tahun 2008 tentang VCO yaitu kadar asam lemak bebas maksimal dalam VCO adalah sebesar $0,2 \%$.

\section{Uji Organoleptik}

Berdasarkan hasil pengujian secara kimia yaitu dengan uji organoleptik dari 11 koresponden didapatkan hasil sebagai berikut:
Tabel. 3. Hasil Uji Organoleptik VCO

\begin{tabular}{|c|c|c|c|c|}
\hline Koresponden & Tekstur & Aroma & Rasa & Wama \\
\hline 1 & suka & suka & suka & suka \\
\hline 2 & suka & netral & sulka & netra! \\
\hline 3 & suka & suka & netral & suka \\
\hline 4 & suka & amat sangat suka & & \\
\hline 5 & netral & sukı & netral & netral \\
\hline 6 & suka & suka & netral & netral \\
\hline 7 & \multicolumn{2}{|c|}{ sangat suka sanagt suka } & netral & agak suka \\
\hline 8 & suka & agak suka & sulka & netral \\
\hline 9 & \multicolumn{2}{|c|}{ sangat suka ticak suka } & netral & sangat suka \\
\hline 10 & & netral & sulka & suka \\
\hline 11 & \multicolumn{2}{|c|}{ sanģat suka suka } & sangat suka & sangat suka \\
\hline Rata-rata & suka & suka & netral & netral \\
\hline
\end{tabular}

Berdasarkan uji hasil pengujian organoleptik dari 11 koresponden didapatkan hasil bahwa tingkat kesukaan dari koresponden terhadap tekstur dari sampel VCO yaitu 7, yang berarti suka. Tingkat kesukaan terhadap aroma dari sampel VCO yaitu 7 , yang berarti suka. Tingkat kesukaan terhadap rasa dari sampel VCO yaitu 5, yang berarti netral. Sedangkan tingkat kesukaan terhadap warna dari sampel VCO yaitu 5, yang berarti netral. Sehingga dapat disimpulkan bahwa koresponden suka terhadap tekstur dan aroma dari sampel VCO yang dibuat dengan fermentasi bakteri asam laktat dan koresponden netral terhadap rasa dan warna dari sampel VCO yang dibuat dengan fermentasi bakteri asam laktat.

\section{KESIMPULAN}

Berdasarkan uji fisik (uji viskositas) menunjukkan sampel $\mathrm{H}$ dengan isolat BUB 3 bahwa nilai viskositas sebesar 58,4325 Pa.s dan densitas $937,5 \mathrm{Kg} / \mathrm{m}^{3}$. Pada uji kimia (uji asam lemak bebas) didapatkan hasil kadar asam lemak bebas sampel H (BUB 3) dengan paling mendekati kadar asam lemak bebas menurut SNI 7381 tahun 2008 tentang VCO yaitu kadar asam lemak bebas maksimal dalam VCO adalah sebesar 0,2\%. Sedangkan berdasarkan uji hasil pengujian organoleptik dari 11 koresponden didapatkan hasil bahwa tingkat kesukaan dari koresponden terhadap tekstur dari sampel VCO yaitu 7, yang berarti suka. Tingkat kesukaan terhadap aroma dari sampel VCO yaitu 7 , yang berarti suka. Tingkat kesukaan 
terhadap rasa dari sampel VCO yaitu 5, yang berarti netral. Sedangkan tingkat kesukaan terhadap warna dari sampel VCO yaitu 5, yang berarti netral.

\section{DAFTAR PUSTAKA}

Ali A, Dwiyana Z. 2005. Bakteri Asam Laktat Potensi dan Peranan dalam Produk Pangan dan Kesehatan, Prosiding Pelatihan Bakteri Asam Laktat. Universitas Hasanuddin Makassar.

APCC, 2010. Coconut Statistical Year Book 2009. Asian and Pacific Coconut Community [APCC]. Jakarta.

Che Man YB, Abdul Karim MIB, Teng CT. 1997. Extraction of coconut oil with Lactobacillus plantarum 1041 IAM. J. Am Oil Chem Soc 74: 1115-1119. DOI: 10.1007/s11746-9970033- 0 .
Fawzya, Y.N. 2010. Bahan Pengawet Nisin: Aplikasinya pada Produk Perikanan. $J$. Squalen 5 (3).

Kusmiati, dan Malik, A. 2002. Aktivitas Bakteriosin dari Bakteri Leuconostoc mesenteroides Pbacl pada Berbagai Media. Makara, Kesehatan. 6 (1).

Setiaji Bambang dan Prayugo Surip.2006. Membuat VCO BerkualitasTinggi. Jakarta: Penebar Swadaya.

Surono IS. 2004. Probiotik: Susu Fermentasi dan Kesehatan. Jakarta: YAPMMI.

Tansakul, A dan Chaisawang, P. 2006. Thermophysical Properties of Coconut Milk. Journal of Food Enginering. 73:276-280. 